How to cite this article

Moulds, S., \& Khoo, Y. H. (2020). The role of the people in post legislative scrutiny: Perspectives from Malaysia and Australia. Journal of International Studies, 16, 1-23. https://doi.org/10.32890/jis2020.16.1

\title{
The Role of the People in Post Legislative Scrutiny: Perspectives from Malaysia and Australia
}

\author{
${ }^{1}$ Sarah Moulds \& ${ }^{2}$ Ying Hooi Khoo \\ ${ }^{1}$ University of South Australia's Justice and Society Unit \\ ${ }^{2}$ Department of International and Strategic Studies, University of Malaya
}

${ }^{1}$ Corresponding author: sarah.moulds@unisa.edu.au

\begin{abstract}
The purpose of this article is to critically examine the role of the people in the process of reviewing the implementation and effectiveness of existing laws, described in the emerging literature as 'post-legislative scrutiny or 'PLS'. Examining the options for citizen engagement with legislative review is critical for all parliamentary democracies grappling with the challenge of rebuilding trust between citizens and institutions. This is because reviewing the content and purpose of proposed and the implementation and impact of existing laws is a way for parliamentarians to give effect to their democratic promise. The methodology employed is qualitative in nature with a tiered approached to identifying and examining the extent to which individuals and non-government actors can contribute to parliamentary review processes in two Westminster-inspired parliamentary democracies: Australia and Malaysia. Using case study examples and examining both structural and cultural features of the systems of legislative review in both systems, this article directly challenges some of the assumptions previously associated with PLS in the existing literature. Experiences of different 'ad hoc' forms of PLS in both Australia and Malaysia suggest that there could be substantial benefits for lawmakers and citizens by moving toward a more deliberative, 'bottom up' approach to PLS in the future.
\end{abstract}

Keywords: Post legislative scrutiny, bottom-up approach, Australia, Malaysia.

\section{Introduction}

As modern democracies grapple with the challenge of (re) engaging voters with democratic institutions, it becomes increasingly critical to carefully examine and assess the processes 
and practices of theses institutions and consider whether they require reform. The review of existing legislation - sometimes described as 'post-legislative scrutiny (PLS)' is one of these processes that is designed to provide an important link between the citizen and the parliament, but may not always live up to its promise. This article explores the key ideas underpinning the concept of PLS, and the assumptions underlying its development and recent implementation. It focuses on looking for ways to expand the idea of PLS to ensure that it is more deliberative, or 'bottom up' in nature, and therefore more likely to provide a meaningful link between the people and the lawmakers in the future. In undertaking this task, the authors acknowledge that they are taking a broad, inclusive approach to PLS that pulls against some of the existing literature in this area. This is deliberate, and designed to prompt scholars from other disciplines, including international studies, law and political science, to engage more directly with this concept.

PLS is a concept that is gaining increasing traction in certain jurisdictions and discourses and yet remains elusive or largely unknown in others. It is most commonly used to refer to a process of parliamentary-led review of enacted legislation, designed to evaluate the implementation and effectiveness of the law and through this process, and in this way, improve the overall quality of parliamentary law making. This article explores what PLS means in the context of parliamentary law making in Australia and Malaysia and considers what the role 'the people' play in this process. It argues that if the asserted benefits of PLS are to be released, 'the people' must play a central role at both the 'trigger' stage of PLS, and during the conduct of the PLS itself. In other words, it argues that PLS must be 'bottom up' or deliberative (Levy et al, 2016) recognising that 'those subject to collective decisions should have voices in the process' (Levy et al, 2016a). This article confronts the conventional top-down approach to making and reviewing legislation and proposes that it is necessary to identify and challenge some of the assumptions inherent in existing definitions or descriptions of PLS. This preliminary analysis of different 'ad hoc' forms of PLS in both Australia and Malaysia suggests that there could be substantial benefits for lawmakers and citizens by moving toward a more deliberative, 'bottom up' approach to PLS in the future.

The first part of the article explores conventional understandings of PLS as reflected in and introduces the conceptual framework and research methodology used in this article. Part two contains the case study analysis from Malaysia and Australia. Part three uses case study examples from Malaysia and Australia to explore the assumptions inherent in current understandings of PLS. It argues that effective public engagement is critical to ensure that PLS delivers its asserted benefits and improves the overall quality of the enacted laws.

\section{What is PLS, and why is it important?}

PLS refers to the practice of reviewing enacted laws to determine whether the provisions have been implemented or enforced and to evaluate the impact or effectiveness of the laws (Law Commission of England and Wales, 2006). As will be discussed further in this article, the term brings with it several assumptions, including that the parliament itself will undertake the review work, and that the criteria for review are capable of being predetermined. 
The term PLS has become increasingly popular in academic commentary (Caygill, 2019; Calpinska, 2006) following the work of the Law Commission of England and Wales in 2006, and more recently through international development activities led by the Westminster Foundation for Democracy (WFD) (De Vrieze \& Hasson, 2016). In response to the 2006 Law Commission Report, a systematic approach to PLS has been developed in the UK Parliament, wherein government departments prepare and publish a report that contains an assessment of whether the law being scrutinised has achieved its key objectives within a period of three to five years. These reports are then subject to further scrutiny by departmental select committees within the Parliament, who also prepare a report on the Act (Caygill, 2019). This system has itself now been subject to review and evaluation for effectiveness and impact (De Vrieze et al, 2018).

The UK systematic approach to PLS has also influenced the development of similar practices in other jurisdictions, particularly those with Westminster-inspired parliamentary practices, or those jurisdictions in receipt of development assistance from UK donors or aid agencies, including the WFD (De Vrieze et al, 2018). Systematic approaches to PLS also exist within a range of diverse parliamentary settings, including in Indonesia, Lebanon and Montenegro where specialist parliamentary committees exist to conduct PLS on a systematic basis (De Vrieze et al, 2018).

Despite these developments, the term remains unknown mainly among lawyers and political scientists outside of the UK, including in Australia and Malaysia. This is not because PLS is absent in these or other jurisdictions, but because it is described differently and undertaken on an ad hoc basis. As observed in the Statute Law Review '[e] valuating the impact and effect of legislation once it has been enacted is a well-recognised and important element of the cyclical nature of most legislative endeavour' (Editorial, Statute Law Review, 2006, iii), however, in many jurisdictions, it is not approached systematically.

This makes articulating a universally accepted definition of PLS challenging. For example, in Australia, the PLS is a not a commonly used term, and if asked, most lawyers and political scientist would say that PLS occurs in three different forms within the Australian system. The first is judicial review of legislation to determine whether it is constitutional or not (Stubbs, 2012). The second is review of enacted legislation by parliamentary committees in response to a sunset provision or part of their broader scrutiny role (Grenfell et al, 2018; Gulati et al, 2012), and a third form of PLS is ad hoc review of enacted legislation by extra-parliamentary bodies, including statutory authorities or Commissions (Williams et al, 2015). It is this second form of PLS that aligns more closely with the way the term has developed in the UK.

This reveals a critical assumption underlying the current description of PLS: that parliament (as opposed to the judiciary or the people themselves) is in control of setting the 'trigger' for PLS to occur and is responsible for conducting the PLS itself. As discussed below, this has implications for the extent to which the community or other non-parliamentary actors can set the criteria for review of enacted legislation or participate in the process of review. While 
this assumption has been qualified in some recent iterations of the idea of PLS (De Vrieze, 2018), it remains a dominant feature that demands further analysis. The assumption that it will be the parliament that is responsible for conducting the PLS also gives rise to a range of complex questions about how PLS should work in practice, and whether and how we should measure whether it is delivering on its stated aims. These questions include:

- $\quad$ Should all enacted legislation be subject to PLS, or just some? If only some, then how should legislation be selected? (Editorial, Statute Law Review, 2006, iv)?

- What should be the 'trigger' for PLS?

- What is the appropriate time frame for PLS to occur?

- By what criteria should the effectiveness of the enacted laws (and the process of PLS) be measured?

This article does not aim to answer these questions, but rather to point to the need to integrate the role of the people of the community in both the conceptual understanding of what PLS is and in the way that PLS is conducted. It is argued that public participation in PLS is critical to ensure its legitimacy and overall effectiveness. These themes are explored further below regarding the case study examples.

Before introducing the case studies discussed in this article, it is important to reiterate why PLS is considered to be necessary and of benefit for both law-makers and citizens. The Law Commission of England and Wales saw the task as necessary in its inquiry into the issue in 2005 and 2006, explaining that PLS can help ensure that enacted laws are being implemented in practice, are giving effect to the 'policy aims avowed' and not having any unintended consequences (Law Commission of England and Wales, 2005). Initiating a systematic approach to the PLS in the UK Parliament was also seen as providing a 'new and significant role for Parliament' by closing the 'scrutiny loop' that begins with pre-enactment scrutiny (usually by specific parliamentary committees) and ends with PLS (Calpinska, 2006, 192).

The broader aims or benefits of PLS have been articulated as 'principles' by the WFD in its London Declaration on Post Legislative Scrutiny, which provides that PLS works as a safeguard, protecting core constitutional values such as representative democracy, legal certainty and the rule of law. The Declaration further explains that PLS involves 'monitoring and evaluating if laws are benefiting citizens as originally intended' and is designed enhance the 'quality and effectiveness of legislation and its implementation' (WDF, 2018, Preamble). Other benefits of PLS derived from the Declaration include its potential to 'increase legislators' focus on implementation and delivery of policy aims and to identify and disseminate good practice' and to improve government accountability (WDF, 2018, Preamble and Principles 1-4).

These aims and benefits suggest that the citizen, or the public at large, is assumed to be a principal beneficiary of effective PLS. This is a laudable goal, but one that this article argues 
can only be achieved if the PLS provides meaningful opportunities for 'bottom up' public engagement at both the 'trigger' and 'process' stages, through a deliberative approach to scrutinising enacted legislation (Levy et al, 2016a; Elster, 1998, p1, 8; Gutmann et al, 1996, p14).

\section{Conceptual Framework}

The conventional approach to law making and to the review of proposed or enacted legislation in Westminster Parliaments has been heavily influenced by the principles of representative decision-making and democratic representation (Jaensch, 2011; Gleeson, 2001; French, 2017; Rankin, 2010). As Jaensch (2011:26) explains, '[d] emocratic representation involves the right of all citizens to elect the people who will represent them' in the Parliament through the electoral system. This system allows individuals to exercise democratic power, but only through the process of electing representatives to Parliament (Pettit, 2001; Applebyet al, 2019).

This approach to law-making and legislative review makes a number of assumptions about the agency of key actors within the system, and in particular, is often blind to the political and practical limitations faced by many electors within modern Westminster democracies when it comes to ensuring elected representatives represent their views or interests. These political and practical difficulties differ across jurisdictions and are undoubtedly different in Malaysia than in Australia. However, some core similarities are apparent across geographical borders: members of minority groups can have their fundamental rights and interests abrogated, those without political or economic power can have their social and economic needs ignored, and elected representatives often priorities party-political agendas over the needs or demands of their electorates.

These features of modern Westminster Parliaments also give way to what this article describes a 'top down' approach to parliamentary law making and review and scrutiny of enacted legislation. This is because, under the conventional model, it is democratically elected parliamentarians often with the advice of Executive Departments or party political decision-makers, that determine when PLS occurs, how it occurs, the scrutiny criteria that applies and sets the practical and political limits on what the outcomes of PLS might be.

The top-down model centres around the authoritative decision-making power of those currently exercising Executive power and those with access to relevant resources (Macdonald 1995, Levit 2005, 2007). Under this model, 'centrally located actors are seen as most relevant to producing the desired effect' (Matland 1995: 146). The main actors, in this context, are the state and executive policymakers, who are regarded as sole decision-makers responsible for formulating and reviewing a statute. These primary actors have a strong influence on the methods of review, and the goals of review and have incentives to minimize the number of non-government actors, who may express different points of view or contest 
the stated policy goals articulated by the Executive (Matland 1995). Such an approach can be criticized on the basis that it elevates the role of those already in positions of law making and executive power, and minimise the opportunities for meaningful deliberation or public engagement with the law-making or legislative scrutiny process ss (Matland 1995; David 1994; Midgley 1993).

This 'top down' model of law making has also been criticised as contributing to an 'implosion of trust' among citizens in their political institutions and law-making bodies (MacKay, 2017). For some of these critics, improving the responsiveness of parliament to the needs of the community, for example through adopting more deliberative approaches to law making and legislative scrutiny, may be part of the solution (Levy et al, 2016a; Elster, 1998:1, 8). As Levy and Orr (2016) explain, deliberative law-making requires an active search for a broad range of information, as well as a process for reflection by decisionmakers and the opportunity to move towards a shared common ground. This approach is in line with legal empowerment and social justice theorists who suggest that a more engaged electorate, with greater access to the law making process, could improve the legitimacy of parliamentary law making and thus enhance the levels of trust associated with key political and law making institutions (Liebenberg, 2018:633, Marshaw 1981:901). This article builds upon these ideas by exploring the benefits and challenges associated with moving from a 'top down' to a 'bottom up' approach to PLS.

A bottom-up approach to PLS emphasizes community participating in decision-making and includes a focus on grassroots mobilisation (Finger 1994, p.32). The bottom-up model also provides space for a broader range of key issues to be introduced, and creates meaningful opportunities for practitioners and the public to discuss issues openly. This approach also enables local issues and concerns to come to the fore, and facilitates the identification of local solutions and innovative strategies to address concerns or shortcomings (Panda 2007). A bottom up approach to PLS also speaks to the broader responsibilities of modern parliaments to reach out to their electorates and explain how their legislative functions the benefit of their community.

Literature on bottom-up approaches to decision making is conventionally applied in the field of community development for the NGO sector (Knoke 1990; Korten 1990; Finger 1994; Schmale 1993; Srinivas 1998). However, this article attempts to situate the bottomup approach in the context of PLS using the case studies of Australia and Malaysia. In this way, we build upon the work of scholars who scholars have explored the gap of lawmaking process from bottom-up model (Levit 2007; Rachlinski 2006; Eskridge Jr. 1994). As explored below, this article argues that it is critical to embrace aspects of bottom up model when undertaking PLS to ensure that the practical benefits of PLS are released - namely to ensure that the laws made by Parliament and meeting the needs of the people they serve (Garza et al., 1988; Ewalt 1997; Navarro 1994). 


\section{Research Methodology}

The complex and dynamic nature of parliaments and parliamentary and external bodies involved in PLS means evaluating their performance, or considering different approaches to the task of PLS, is not always straightforward (Russell et al, 2009; pp.111, 113; Larkin et al, 2009; Tolley, 2009; Evans et al, 2006; Smookler, 2006; Williams et al, 2016). Many scholars have grappled with these challenges when seeking to evaluate the performance of parliamentary-based bodies or functions in a range of different areas (see e.g Kavanagh, 2015; Griffith, 2005; Halligan, 2008; Tolley, 2009). The evaluation framework applied in this research aims to address these challenges (Evans et al, 2006; Campbell et al, 2015; Kinley, 1999; Kinley et al, 2012) by adopting a holistic approach to evaluating a select range of case studies relating to PLS. This approach involves a combination of the following four key steps:

- Describing the institutional context in which the PLS takes place in each jurisdiction.

- Identifying the role, functions and objectives of the body undertaking the PLS, having regard to the trigger points for PLS, the scrutiny criteria applied and the impact of the scrutiny on the content and implementation of the law.

- Identifying key participants and determining their views as the legitimacy (see e.g Beetham, 2002; Kant, 1999; Knight et al, 1994; Manin, 1987; Nagel, 1987; Riely, 1982; Turner, 2014; Fukuyama, 2015) of the PLS process. For example, the key participants in the Australian parliamentary committee system include parliamentarians, elected members of the executive government, submission makers and witnesses to parliamentary committee inquiries, public servants and government officers, independent oversight bodies and the media

- $\quad$ Reflecting on the value or benefits of the PLS process.

Both authors have had the first-hand experience through direct involvement in the nongovernmental organizations (NGOs) advocating for law reforms in the parliament. This provides new and different forums for communities and individuals to engage with parliamentarians and relevant stakeholders. The insights obtained from this approach gives rise to the potential for a more holistic understanding of the process of PLS, which has informed a number of the features of this paper.

\section{Case Studies from Malaysia and Australia}

\section{Malaysia}

After gaining independence from the British in 1957, the Malaysian government was developed having regard to the Westminster model of parliamentary democracy, complemented with a constitutional monarchy in the form of Yang di-Pertuan Agong (the King) as the federal head of state (Maria, 14 March 2019). Academic literature on Malaysia 
has categorised its political system in various terms, such as "quasi-democracy" (Zakaria, 1989) and soft authoritarianism (Means, 1996). The common theme is that Malaysia's parliamentary system is attributed with a hybrid character that combines both democratic and authoritarian features (Mauzy, 2006). Understanding Malaysian parliamentary effectiveness requires an examination of the impact of its democratic trajectory on broader society. In the $14^{\text {th }}$ general elections held on 9 May 2018, the people voted out the Barisan Nasional (BN), the political coalition that had ruled Malaysia since the country's independence in 1957, in favour of the then-opposition coalition, the Pakatan Harapan (PH).

Before the election, fundamental rights of freedom of expression, peaceful assembly and association were mostly curtailed ranging from the restrictions to the opposition politicians to the civil society groups. Government bureaucracy has been charged with being inefficient, corrupt and ineffective at protecting and promoting the public interest. This has led to growing public concern over the lack of accountability and responsiveness within government, and the poor performance of the bureaucracy. A total of 60 promises and five special commitments were made in PH's election manifesto (Pakatan Harapan, 2018). A significant number of these promises entail institutional, legislative and parliamentary reforms (Lee, 2018).

Parliament is recognized as one of the starting points for the reform agenda to take place (Maria, 14 March 2019). One of the key parliamentary reforms is to strengthen the function of parliament by establishing more bi-partisan special select committees, made up of several parliamentary members that are appointed to deal with a particular issue or area of issues. The mechanism of the special select committees originates in the Westminster system of parliamentary democracy, to ensure there are checks and balance measure in place.

In Malaysia, the legal framework for select committees exists under the Parliament's Standing Orders (SOs). Currently, the SOs of the Dewan Rakyat or House of Representatives provide for the establishment of five existing select committees: (1) the Committee of Selection (SO 76); (2) the Public Accounts Committee (SO 77); (3) the Standing Orders Committee (SO 78); (4) the House Committee (SO 79); and (5) the Committee of Privileges (SO 80). It also allows for the establishment of special select committees when needed and for specific cases of particular concerned interest. Such a model of committees serves on a limited period with specific terms of reference that governed the role and function of such committees.

However, in practice, there is limited use of these committees to facilitate the parliamentarians to undertake their functions. It is the Attorney General's Chambers, upon advice of the Executive Government that primarily responsible legislative drafting. The component of PLS is significantly missing from the existing five SOs of the Dewan Rakyat. It is often criticised that the Dewan Negara or Senate merely rubber stamps bills to become law. For instance, while the Parliament of Malaysia has established the Public Accounts Committee, in which it has produced reports and also debate sessions that took place in the Parliament, there have been no conclusions or sanctions of those responsible for financial 
losses (Malaysian Economic Association, 2017). The quality of the scrutiny experience is often dependent on the extent to which public servants are able or willing to respond to the queries raised by parliamentarians.

Under Promise 16 of the PH election manifesto (Pakatan Harapan, 2018), the PH has pledged to restore the dignity of the Parliament, recognizing the critical role it plays in holding the Executive to account for the powers its exercises, and acknowledging that Parliament must have sufficient infrastructure and funding. In its manifesto, it has also mentioned that the PH government if they come into power, they will reintroduce the Parliamentary Services Act 1963, with improvements in some issues so that the Act is applicable for the current environment. The manifesto also mentioned that the Speaker of the Dewan Rakyat and the President of Dewan Negara would be members whose integrity and credibility are respected by their peers; they must retire from partisan politics as soon as they accept their posts. Besides, a special committee will be formed to receive and examine complaints from the MPs to ensure that their decisions are fair. Promise 16 also highlighted that the Leader of the Opposition would be granted the status and provisions equivalent to a Federal Minister. Under the proposed reforms, funding would be distributed to all members of the Dewan Rakyat pursuant to a transparent formula, to enable members to fulfil their responsibilities in their respective constituencies and to run their service centres. The select committee system with suitable provisions and appropriate support staff to enable them to function effectively will be established. For instance, a Dewan Rakyat select committee will be established to monitor every ministry, with the power to call Ministers and senior officials to appear and give evidence.

Promise 16 (Pakatan Harapan, 2018) also includes the key provisions on more transparent appointment procedures to key national institutions such as the Human Rights Commission of Malaysia (SUHAKAM), Election Commission (EC), the Malaysian Anti-Corruption Commission (MACC), and Judicial Appointments Commission (JAC) to be approved by a suitable parliamentary committee. Similar procedures also envisage applying to key bodies such as the Attorney General's Chambers, Bank Negara or National Bank, the Securities Commission (SC), and the National Audit Department. At the same time, Promise 16 also includes the vital role of establishing informal groups in Parliament to allow for more exchange of views between Members of Parliament and the civil society.

As a measurement to ensure that the people and all stakeholders can be engaged in the policymaking process as emphasized in the bottom-up model that this paper uses, Promise 16 also emphasized the need to start the culture of producing Green Papers to stimulate discussions and White Papers to announce significant government policies before a new Act was introduced in Parliament. For instance, Senate Reform Working Committee has called for the restoration of the Parliamentary Services Act 1963, which was repealed in 1992, to increase the autonomy of Parliament. Significantly, this Act would ensure the separation of powers between Parliament and other jurisdictions. This is seen as a crucial step to do away with the "rubber stamp" label formerly given to Parliament, attributing the perception to a 
lack of media coverage and communication with the public (Aris, 18 February 2019), in which this can open the door for the PLS mechanism to be put in place.

Due to these shortcomings, the on-going parliamentary reforms recognise the need for a mechanism to enable legislation to be debated thoroughly with the MPs to have more time to consider the various implications of the legislations. The proposal of suggesting the need for a mechanism for greater public scrutiny of bills leading to better legislation and its implementation is not new, for instance, has been proposed previously by the Malaysian Economic Association (2017). This measure is deemed crucial because, in the past regime, the MPs were often not given sufficient time to examine the new Act before its tabling. There was also almost no room for scrutiny after the Act is approved and implemented as envisaged in the mechanism of PLS.

The Parliament's role in the legislative process in Malaysia is undermined by the Cabinet's pervasive dominance that leads to the weakness in the matter of parliamentary scrutiny of bills. As gathered through the author's advocacy experience, one main reason of this is due to the reality of political loyalties that prevents objective consideration of the bills that are tabled, whereby voting for or against is solely based on party lines. A study undertook in 2017 by the Malaysian Economic Association revealed that $80 \%$ of bills introduced by the executive are passed without any substantive amendments, with only $15 \%$ undergo some changes, while another $5 \%$ are either withdrawn or postponed by the executive.

The legal mechanism for Parliament to appoint special select committees is provided under Order 81 of the SOs. The committee of selection nominates members of special select committees, but they have the power to elect their chairperson. Select committees can require documents and other materials to be produced, and have the power to compel witnesses to appear and give evidence. The Committee of Selection, except for the Committee of Selection itself, whose members are appointed by the Dewan Rakyat, nominates the members of the select committees. The Speaker, except for the Public Accounts Committee, chairs each of the above select committees. The Dewan Rakyat appoints the Chairman and Deputy Chairman of the Public Accounts Committee. Order 81 of the SOs empowers the Dewan Rakyat to establish select committees other than the five mentioned earlier. The purpose of the special select committees is to inquire into and deliberate on such matters as determined by the Dewan Rakyat. In terms of the composition of these committees, SO 82(1) states that every select committee shall, so far as a practicable, reflect the balance of parties within the Dewan Rakyat. A select committee has the power to compel any person to appear before it and to ask for the production of documents and papers. Thus, parliamentary select committees are potentially powerful tools to call the for more government accountability (Hishamudin, December 2016).

Since the change of government, six new bi-partisan parliamentary select committees have been formed, namely the Consideration of Bills Committee; the Budget Committee; the Rights and Gender Equality Committee; the Major Public Appointments Committee; the Defence and Home Affairs Committee; and the Federal State Relations Committee. Also, 
one newly introduced Parliamentary Caucus on Reforms, in which the opposition has been allocated two places in each committee. Apart from that, a Special Cabinet Committee was also set up to review the implementation of the Malaysia Agreement 1963 (MA63) concerning the status of Sabah and Sarawak in East Malaysia (The Star, 10 May 2019). A Select Committee for the $14^{\text {th }}$ Parliamentary Term, chaired by Dewan Rakyat Speaker Datuk Mohamad Ariff Md Yusof is also formed (The Star, 10 May 2019).

The setting up of the parliamentarian select committees is not a new phenomenon in Malaysia. Such committees existed before the new government; the difference is that this new government has increased its level of engagement with these bodies, emphasizing the role of the parliamentarian members and the role of the Parliament as a whole in the process of pre and post legislative review. However, despite these promising beginnings, discussion with various stakeholders and observers reveal fundamental weaknesses in the decisionmaking process of the legislature. Although scrutiny mechanisms such as parliamentary committees are given formal status and structure, thus far, there has been limited use of parliamentary select committees in the Malaysian parliamentary practice. Similarly, while the Standing Orders exist to provide a legal framework for such bodies, actual outputs and impact has been minimal.

Given these challenges, the setting up of a Considerations of Bills Committee, for instance, provides a promise of improved participation by affected interests in the legislative process, which if realised in practice could give rise to a more thorough, constructive, systematic, non-partisan scrutiny of draft Bills. There is some reason for hope that this promise may come to pass - since the change of government, the notion of public participation in matters related to the government has increased. However, the critical question of implementation remains: a challenge compounded by the partisan politics that continues to overshadow the broader scrutiny and deliberative roles of the Malaysian Parliament when it comes to legislative review. As discussed below, the challenge of executive dominance and partisan politics is not unique to Malaysia, and is also present in the Australian context, which employs its own, slightly different forms of ad hoc legislative review.

\section{Australia}

This next section of the article reflects on how PLS occurs in the Australian context, and begins to identify the potential ways in which the existing ad hoc, 'top down' approach to PLS in Australia can give way to more deliberative, 'bottom up' practices with key benefits for both law-makers and the community. The approach to PLS at the federal in Australia can be described as 'ad hoc' because unlike some other jurisdictions, it does not have a prescribed or systematic approach to pre and post legislative scrutiny or a single body charged with initiating or conducting PLS. Instead, it relies upon scrutiny undertaken by parliamentary committees, the practice of including sunset clauses in legislation from time to time, and the activity of statutory bodies with various powers to review enacted legislation against a range of prescribed criteria (Grenfell, 2015). For example, the Australian Human Rights Commission (AHRC) has an explicit statutory mandate to provide advice about 
the human rights compliance of Australia's federal laws. However, although the AHRC can have powerful legislative impacts, in practice the legislative scrutiny they conduct is confined to only a tiny handful of federal laws and is conducted on a thematic rather than systematic basis.

The most sophisticated system of legislative scrutiny occurs at the federal level (Grenfell \& Moulds, 2018), and for that reason, this article focuses on the effectiveness and impact of scrutiny in the Australian Parliament. At the federal level, the Parliament comprises of two Houses - the House of Representatives (with members elected by constituents from equally sized electorates) and the Senate (with members elected on a proportional basis, to provide equal representation for each state) (Appleby, Grenfell and Reilly, 2019, pp.130-143). The Senate is often described as a House of Review (Mulgan, 1996), and plays a central role in scrutinising proposed laws and executive action. The parliamentary committee system at the federal level includes committees with broad powers to conduct public inquiries into Bills and other matters (described as 'inquiry-based committees') and committees that scrutinise proposed laws concerning certain prescribed criteria (described as 'scrutiny-committees').

The inquiry-based committees, such as the Senate Standing Committees on Legal and Constitutional Affairs, have powers to hold public inquiries into any Bills or existing laws that are referred to them by Parliament (Senate, Parliament of Australia, Standing Order 25 (2000)). The relevant Standing Orders prescribe the membership of these committees, and sometimes include a majority of government members and sometimes include a nongovernment majority. For example, the Senate Legal and Constitutional Affairs Legislation Committee as a government Chair and a majority of government members, while the Senate Legal and Constitutional Affairs References Committee has an Opposition Senator as Chair and a majority of non-government members. Senate establishes both committees, Parliament of Australia, Standing Order 25 (2000).

These committees can also include 'participating members' who join the committee for a particular inquiry, making them politically diverse and dynamic forums for engaging with contested policy issues. The federal Parliament also includes some specialist committees established by statute with specific functions and powers. One such committee is the Parliamentary Joint Committee on Intelligence and Security (Intelligence Services Act 2001 (Cth) Part 4), which is given a specific mandate to review the operation, effectiveness and implications of a number of specific national security laws (s29). This Committee has engaged in ad hoc PLS of many of Australia's counter-terrorism laws, triggered by the use of sunset or review clauses in the original or amending legislation, designed to hold the Executive Government and its agencies to account for the extraordinary powers it was granted to investigate, prosecute, prevent and deter terrorist activity in Australia (Gulatiet al, 2012; Finn, 2010; Ip, 2013).

The scrutiny-based committees in the federal system include the Senate Standing Committee for the Scrutiny of Bills (Standing Order 24(2)(a) (2017)) and the Parliamentary Joint 
Committee on Human Rights (Human Rights (Parliamentary Scrutiny) Act 2011 (Cth) s 4.). These scrutiny-based committees are required to review every single Bill (and in the case of the Human Rights Committee, all legislative instruments) for compliance with a range of scrutiny criteria, including criteria that relate to individual rights and liberties (Human Rights (Parliamentary Scrutiny) Act 2011 (Cth) s3). These committees rarely hold public inquiries, but they regularly produce written reports and engage in correspondence with proponents of the Bill, highlighting any areas of concern or non-compliance with their respective scrutiny criteria. The inquiry-based committees and their submission makers can then use these scrutiny reports, to draw attention to particularly concerning features of the proposed law or policy.

It is important to note that while both of these Committees are required to scrutinise Bills, there is no corresponding duty to engage in the scrutiny of enacted provisions. The Scrutiny of Bills Committee is given no powers to initiate inquiries into enacted legislation, and while the Human Rights Committee can review existing legislation for compliance with prescribed human rights in practice, it has exercised this power only very rarely (Human Rights Committee, 2017). This means that there is no systematic approach to PLS in Australia. Unlike the UK Parliament, the Australian Parliament does not employ the practice of requiring Executive Departments to issue memorandums of implementation like the British Parliament, or mandate post-enactment scrutiny as part of the committee's primary role, as the Indonesian Badan Legislasi (De Vrieze et al, 2018; pp.14-17, pp.24-26). Instead, there is a range of different 'trigger points' (De Vrieze, 2018: 5) for PLS at the federal level in Australia - almost all of which engage the parliamentary committee system in some way.

In addition to the above 'top down' triggers for PLS described above, there is also the potential for PLS to occur in response to calls for review by the community. The 2008 review into the effectiveness of the Sex Discrimination Act 1984 (Cth) by is an example of a pro-active, Parliament-initiated post-legislative scrutiny, which responded to strong calls for review into this legislation by community groups (Morgan, 2004). This review of proved to be extensive both in terms of scope and public engagement. The LCA Committee's terms of reference reflected the issues community groups and advocates had been raising with parliamentarians for some time, as well as findings of past inquiries into aspects of the legislation (House of Representatives Standing Committee on Legal and Constitutional Affairs, 1994; LCA Committee, 2008). The broad scope of these terms of reference is reflective of a more 'bottom-up' or deliberative approach to PLS, where the criteria to be applied during the scrutiny process are developed with community input, as well as parliamentary direction. Some of the most significant, and controversial recommendations arising from the Report, responded to community calls to clarify or reconceptualise critical aspects of the legislation's policy aims and scope.

The numerous parliamentary committee reviews of the Marriage Act 1961 (Cth) also provide an example of the capacity of the Australian federal parliamentary committee system to provide an avenue for 'bottom up' PLS. Numerous parliamentary committee inquiries into the question of whether the Marriage Act should be amended to enable same-sex couples 
to legally marry attracted tens of thousands of submissions (LCA Committee 2012,) and the reports of these committees provided powerful indicator of a shift in public support in favour of marriage equality. This form of PLS was supplemented by efforts to more directly engage the Australian community in the form of a voluntary 'postal survey' of all Australians who have enrolled to vote. The survey asked votes for their views on 'whether or not the law should be changed to allow same-sex couples to marry (McKeown, 20162018). These two Australian examples provide a new perspective from which to consider the deliberative benefits of PLS, if the right conditions are provided to enable a 'bottom up' approach to emerge, or at least co-exist with the convention 'top down' approaches to legislative review.

\section{Analysis}

\section{Differences in approaches to PLS}

The data collected reveals that there were significant differences in the way that the parliaments in Malaysia and Australia approached the process of PLS. For example, the recognition of the importance of legislative scrutiny at various stages is acknowledged in the newly formed Malaysian Consideration of Bills Committee. Its implementation has thus far been slow, but the pressure imposed by the civil society groups is increasing. In Australia, multi-faceted scrutiny of proposed and existing laws occurs across the parliamentary committee system but remains largely ad hoc in nature.

These differences give rise to particular challenges when considering how to re-conceive of PLS from a 'bottom up' perspective. In Malaysia, these challenges take the form of structural and political resistance to engage in a direct or meaningful way with community organisations or individuals who may hold strong views against particular aspects of government policy or decision making, or who may represent previously marginalised minority groups. These challenges cannot be divorced from Malaysia's political and constitutional history and are exacerbated by other contributing factors including lack of press freedom and experiences of government corruption. In the current political climate, there is evidence to suggest that the new Malaysian Government is more willing to engage with a broader range of MPs as part of the parliament's scrutiny role.

In Australia, the challenges associated with moving away from the conventional 'top down' model of parliamentary law making and PLS may be less acute but remain significant. For example, unlike many other modern democracies, Australia does not have a constitutional or statutory Bill of Rights or other judicial-based systems of reviewing enacted laws for compliance with rights-based criteria (Banfield \& Knopff, 2009). Instead, it relies exclusively on a parliamentary model of rights protection (Williams \& Burton, 2013) and an ad hoc system of PLS. This means that just like the Malaysian Parliament, the Australian Parliament remains susceptible to executive dominance particularly when it comes to parliamentary inquiries into proposed or existing laws 
However, the Australian experience suggests that despite the risk of executive dominance within its parliamentary committee system, it remains possible for PLS to have positive impacts on the content of federal law, and on the way the law is implemented din practice Moulds, 2018). The counter-terrorism, sex discrimination and marriage equality examples discussed above illustrate that these results are most likely to occur when the PLS includes 'bottom up' or deliberative features, such as the opportunity for the public to engage directly at both the 'trigger' and the scrutiny stages, and when multiple scrutiny bodies are engaged in the PLS process. For these reasons, the Australian experience may provide some crucial insights into how existing parliamentary mechanisms can be adapted or built upon to facilitate a more deliberative, 'bottom up' approach to PLS.

\section{Towards a more deliberative, 'bottom up' approach to PLS?}

The Australian and Malaysian experience of PLS to date, with its various trigger points and ad hoc approach to reviewing enacted laws offers some insights into how traditional 'top down' models of parliamentary law making can be adapted to facilitate more deliberative forms of law making, to at least provide the right conditions for 'bottom up' approaches to PLS to be explored. While there are differences in both countries' approaches and paces in PLS, this article identified three key strategies as particularly relevant to addressing the challenges identified above:

a. Investing in the deliberative capacity of parliamentary committees as a beneficial supplement to other forms of direct community engagement,

b. Creating the right scrutiny culture within the parliament and the community to facilitate meaningful public engagement with PLS,

c. Providing a structural pathway or 'trigger' for 'bottom up reform.

Each of these issues will be explored briefly below.

a. Investing in the deliberative capacity of parliamentary committees as a beneficial supplement to other forms of direct community engagement

The experience of parliamentary committee engagement with the issue of marriage equality and sex discrimination laws in Australia suggests that the parliamentary committee system can be used as an effective deliberative forum to gather community views and provide a 'safe space' for parliamentarians to adjust or even shift their public position on a Bill or amendment In the marriage equality example discussed above, it is possible to see parliamentary committees working together over time to develop the political commitment and identifying the legal options needed to advance the marriage equality reforms. The committee system also provided a beneficial supplement to direct democracy approaches (such as postal surveys and plebiscites) to resolving policy issues involving minority rights. Undoubtedly other factors had an impact on the final result, including the provision of a conscience vote by both major political parties. Despite this, the role of parliamentary committees in this reform is crucial because (if properly constituted and resourced) they 
can both (a) act as a meaningful restraint on executive dominance by testing or challenging policy objectives and legislative implementation and (b) temper and moderate the findings of other forms of engaging directly with the public, such as polling or online surveys.

Similar opportunities for meaningful public engagement with parliamentary scrutiny present themselves in Malaysia, particularly following the institutional reform after the change of government. However, thus far, there has been limited use of parliamentary select committees in the Malaysian parliamentary practice. This exposes the reality that legal frameworks for PLS are not of themselves capable of delivering practical outcomes unless accompanied by the requisite political will. Non-government actors and civil society may have to countenance alternative avenues for engaging with the Malaysian parliamentary committee system in order to take advantage of the potential benefits identified in the Australian example.

b. Creating the right scrutiny culture within the parliament and the community to facilitate meaningful public engagement with PLS

The case study analysis in Part Two of the article suggests that improving the diversity of submission makers and other stakeholders with influence over the when and how PLS occurs, can be particularly important in terms of moving towards a 'bottom up approach' (Marinac, 2003). This points to the need for existing PLS bodies such as parliamentary committees and statutory agencies to embrace proactive strategies to attract a more diverse range of submission makers, including updating and expanding invited submission maker lists to ensure individuals and groups beyond the 'usual suspects' are actively encouraged to participate. It could also mean supporting 'new' submission makers by facilitating regular workshops for submission makers and witnesses or establishing a modest hardship fund to support non-government witnesses travelling from regional or remote locations to attend public hearings in person. This is the type of active search for information and meaningful engagement with different perspectives that (Levy et al, 2016) consider being at the heart of deliberative decision-making, and could be beneficial for development aid partners such as WFD to keep in mind when developing programs aimed to promoting and implementing PLS.

The Part Two case studies also underscore the integral role the elected representatives play in facilitating meaningful deliberative forums for scrutiny to take place and establishing the 'culture' of the PLS body including how decision-making processes will work in practice. Targeted support may be needed to ensure that less experienced committee Chairs or other leaders of PLS bodies are well placed to undertake this role, particularly in the Malaysian context where many MPs may not have experience at engaging directly with the public in parliamentary committee work.

Improving communication between parliamentary decision makers and community based participants not only contributes to the system's capacity to provide a deliberative forum but can also act as a conduit for improved media coverage of the work of PLS bodies, 
which in turn broadens the accessibly of the PLS process and creates the right conditions for a 'bottom up' approach to lawmaking. The Australian experience suggests that the key to generating substantial media coverage is to attract and retain sophisticated or influential submission makers who proactively utilise the PLS as a vital plank of a broader media strategy. Once these sophisticated submission makers regard the PLS body as a 'forum of choice', they are likely to orient their public advocacy around the committee, which in turn increases executive attention on the committee's work (House of Representatives Standing Committee on Procedure, 2010:6).

As noted above, the relationship between the executive government and the PLS system is a critical determinative factor in terms of achieving legislative change, and demonstrating to the broad community that PLS is valuable, useful and worth engaging in. This means that it is imperative that proponent Ministers communicate effectively with PLS bodies. Achieving this level of Executive support for PLS is a challenge in both Australia and Malaysia but could be supported by using legislation to require responsible Ministers to respond to the requests for information from PLS bodies as soon as possible, or by requiring that government to respond to the findings of PLS within a prescribed period (see e.g. Agreement for Better Parliament, 2010).

\section{c. Providing a structural pathway or 'trigger' for 'bottom up' reform}

Neither the Australian or Malaysian systems of PLS (or more structured forms of PLS employed in the UK and other jurisdictions such as Indonesia) have an exclusively 'bottom up' processes for commencing the process of PLS, and for determining the scope of the scrutiny criteria to be applied. In other words, there is currently no mechanism that can be utilised by the community or non-government organisations independently of the Parliament to trigger PLS.

There are many good reasons why this is the case, predominately based around the essential and influential principle of representative democracy (discussed early in this article). In short, within Westminster parliamentary democracies, it is the parliamentarians (the elected representatives) that are given exclusive control over law making, and thus it is natural that they have exclusive control over pre and post legislative scrutiny. This concept has been applied more flexibility in modern times, notably through the establishment of statutory bodies and commissions (such as the AHRC) who have the power to identify particular laws for review and inquiry and report on their effectiveness against prescribed criteria. Indeed, the community and non-government organisations can actively participate in this process and can sometimes provide the basis for parliament to proactively review an existing law (such as in the case of the Australian Sex discrimination Act discussed above). However, there is no stand-alone legal mechanism that the community can use to trigger PLS, and the need for such a trigger also appears to be absent in the prevailing literature on this topic.

This article argues that this issue needs to be considered carefully by scholars and lawmakers. Designing a community based, 'bottom up' trigger for PLS - such as through a petition- 
based model could significantly enhance the deliberative quality of PLS in Malaysia and Australia without requiring substantial structural change. Such petition models already existing for raising other matters of parliamentary importance (for example, individuals and organisations can present petitions to either House of the Australian Parliament on points of public policy or to lodge a grievance, Senate Standing Orders $69-71$ ) and could be readily utilised in this forum.

\section{Conclusion}

This article has outlined an important new perspective from which to understand and evaluate the concept of PLS in two very different Westminster-based parliamentary systems. It argues that both the Malaysian and Australian systems have the capacity to move from a 'top down' approach to PLS, towards a more deliberative, 'bottom up' approach if important conceptual and practical challenges can be overcome. These challenges are more acute and broad ranging in the Malaysia context, but also feature in the Australian system, and include the following:

- The dominance of the executive government over parliamentary and nonparliamentary forms of scrutiny and review;

- The lack of resources available to scrutiny bodies to engage with community organisations or to conduct direct democracy-style activities such as postal surveys or online polls;

- $\quad$ The lack of capacity or resources within the community and non-government sector to generate effective advocacy strategies targeting PLS processes.

Despite these challenges, and a strong cultural tradition of 'top down' law making, the Australian parliament has begun experimenting with new ways of engaging the community in the process of parliamentary law making, and offers important insights into how existing parliamentary committee system can be utilised to facilitate a more deliberative, 'bottom up' approach to PLS. It suggests that Westminster Parliaments can begin to re-conceptualise PLS as a 'bottom up' activity by:

a. Investing in the deliberative capacity of parliamentary committees as a beneficial supplement to other forms of direct community engagement such as the use of surveys or online polling;

b. Creating the right scrutiny culture within the parliament and the community to facilitate meaningful public engagement with PLS, for example through financial and practical support for individuals and organisations to provide written or oral submissions to committees or to undertake independent research in the implementation of enacted laws;

c. Providing a structural pathway or a 'trigger' for 'bottom up' PLS to commence for example through a citizen led petition or recommendation by a non-government body. 
This article argues that these strategies, and others designed to improve public engagement with PLS, would have significant benefits for lawmakers and the community. By directly engaging the people at all stages of the review process, a 'bottom up' approach to PLS would provide the right conditions the lofty aims of PLS to be realised. As the WFD espouses, in the right conditions, PLS can work as safeguard, protecting core constitutional values such as representative democracy, legal certainty and the rule of law and improve the quality and effectiveness of legislation and its implementation. This article suggests that moving from a 'top-down' to a 'bottom up' approach is critical to turning these promises into reality.

\section{Acknowledgement}

This paper received no grant or other forms of funding.

\section{References}

Abdullah, M. C. (2019, March 14). Time for parliamentary reform. The Sun Daily. Retrieved from https:/www.thesundaily.my/opinion/time-for-parliamentary-reformGM680923

Appleby, G., Reilly, A., \& Grenfell, L. Australian Public Law (Oxford: Oxford University Press, 3rd ed, 2019) 169-171.

Aris, N. A. (2019, February 18). Senator wants Parliamentary Services Act restored for greater parliamentary autonomy. Free Malaysia Today. Retrieved from https:// www.freemalaysiatoday.com/category/nation/2019/02/18/reforms-committee-chiefwants-parliamentary-services-act-1963-restored/

Banfield, A.C., \& Knopff R. (2009). Legislative versus judicial checks and balances: Comparing rights policies across regimes. Australian Journal of Political Science, 44(1), 13-27.

Beetham, D. (2002). The Legitimation of Power. London: Palgrave.

Bennett, S. (2004). The Australian senate. Research Paper No 6, Parliamentary Library, Parliament of Australia. Retrieved from $<$ https://www.aph.gov.au/About_Parliament/ Parliamentary_Departments/Parliamentary_Library/pubs>. Accessed 8 Jan 2020.

Benton, M., \& Russell, M. (2013). Assessing the impact of parliamentary oversight committees: The select committees in the British House of Commons, Parliamentary Affairs, 66(4), 772-797.

Buchanan, A. (2002). Political legitimacy and democracy. Ethics, 112(4), 689-719.

Calpinska, L. (2006). Post-legislative scrutiny of acts of parliament. Commonwealth Law Bulletin, 32(2), 191-204.

Cassey Lee (2018). Making Sense of Malaysia's Institutional Reforms, No 79, ISEAS: Singapore.

Caygill, T. (2019). Legislation under review: An assessment of post legislative scrutiny recommendations in the UK parliament. Journal of Legislative Studies, 25(2), 295313. 
De Vrieze, F. (2018) Principles of Post-Legislative Scrutiny by Parliaments (2018, Westminster Foundation for Democracy, London). Retrieved from <https://www. wfd.org/approach/post-legislative-scrutiny/>. Accessed 10 Jan 2020.

De Vrieze, F., \& Hasson, V. (2018). Post Legislative Scrutiny: Comparative Practices of Post-Legislative Scrutiny in Selected Parliaments and the Rationale for its Place in Democracy Assistance (Westminster Foundation for Democracy, London). Retrieved from < https://www.wfd.org/wp-content/uploads/2018/07/Comparative-Study-PLSWEB.pdf $>$. Accessed 10 Jan 2020.

Edelman, R. (2017). Executive Summary, 2017 Edelman Trust Barometer, (online) January 15, 2017, Retrieved from <https:/www.edelman.com/research/2017-edelman-trustbarometer $>$. Accessed 10 Jan 2020.

Editorial. (2006). Post-legislative scrutiny. Statute Law Review, 27(2), iii-vi.

Elster, J. (1998). Introduction. In J. Elster (Ed.), Deliberative democracy (pp. 1-18). Cambridge: Cambridge University Press.

Evans, C., \& Evans S. (2006). Legislative scrutiny committees and parliamentary conceptions of human rights. Public Law, 785-806.

French, R. (2017). Law making in a representative democracy: The durability of enduring values. Flinders Law Journal, 19(1), 19-36.

Fukuyama, F. (2015). Why is democracy performing so poorly? Journal of Democracy, 26(1), 11-20.

Gleeson, M. (2001). The shape of representative democracy. Monash University Law Review, 27(1), 1-11.

Grenfell, L. (2015). An Australian spectrum of political rights scrutiny: Continuing to lead by example? Public Law Review, 26(1), 19-38.

Grenfell, L., \& Moulds, S. (2018). The role of committees in rights protection in federal and state parliaments in Australia. University of New South Wales Law Journal, 41(1), 40-79.

Griffith, G. (2005). Parliament and accountability: The role of parliamentary oversight committees. Briefing Paper No 12/05, Parliamentary Library Research Service, New South Wales. Retrieved from <https://www.parliament.nsw.gov.au/researchpapers/ Documents/parliament-and-accountability-the-role-of-parlia/Parliament $\% 20$ and $\% 20$ Accountability\%20BRIEFING\%20Paper\%20and\%20INDEX.pdf>. Accessed 10 Jan 2020.

Gulati, R., McGarrity N., \& Williams G. (2012). Sunset clauses in Australian anti-terror laws. Adelaide Law Review, 33, 307-333.

Gutmann, A., \& Thompson, D. F. (1996). Democracy and disagreement. Cambridge, Massachusetts: Harvard University Press.

Habermas, J. (1995). Reconciliation through the public use of reason: Remarks on John Rawls's political liberalism. The Journal of Philosophy, 92(3), 109-131.

Halligan, J. (2008). Parliamentary committee roles in facilitating public policy at the Commonwealth level. Australasian Parliamentary Review, 23(2), 135-156.

Jaensch, D. (2011). Democratic representation: Then, now, and in the future. Flinders Journal of History and Politics, 27, 26-34. 
Kant, I. (1996). The Cambridge edition of the works of Immanuel Kant: Practical philosophy. Cambridge: Cambridge University Press.

Kavanagh, A. (2015). The joint committee on human rights: A hybrid breed of constitutional watchdog. In M. Hunt, H. J. Hooper \& P. Yowell (Eds.), Parliaments and human rights: Redressing the democratic deficit (111-134). Oxford: Hart Publishing.

Kinley, D. (1999). Parliamentary scrutiny of human rights: A duty neglected. In P. Alston (Ed.), Promoting human rights through bills of rights: Comparative perspectives (158-172). Oxford: Oxford University Press.

Kinley, D., \& Ernst, C. (2012). Exile on main street: Australia's legislative agenda for human rights. European Human Rights Law Review, 1, 58-70.

Knight, J., \& Johnson, J. (1994). Aggregation and deliberation: On the possibility of democratic legitimacy. Political Theory, 22(2), 277-296.

Koziol. M., \& Political reporter. (2017, January 21). Distrustful nation: Australians lose faith in politics, media and business. The Sydney Morning Herald. Retrieved from https://www.smh.com.au/politics/federal/distrustful-nation-australians-lose-faith-inpolitics-media-and-business-20170118-gttmpd.html

Larkin, P., Hindmoor A., \& Kennon A. (2009). Assessing the influence of select committees in the UK: The education and skills committee 1997-2005. Journal of Legislative Studies, 15(1), 71-89.

Law Commission of England and Wales (2006) Post legislative scrutiny (October 2006) Cm 6945. Retrieved from <http://www.lawcom.gov.uk/app/uploads/2015/03/lc302_ Post-legislative_Scrutiny.pdf $>$. Accessed 10 Jan 2020.

Law Commission of England and Wales, (2005). Ninth Programme of Law Reform (Law Com No 293). Retrieved from < https://s3-eu-west-2.amazonaws.com/lawcom-prodstorage-11jsxou24uy7q/uploads/2015/03/lc293_9th_Programme.pdf $>$. Accessed 10 Jan 2020.

Levy, R., \& Orr, G. (2016). The law of deliberative democracy. London: Routledge.

Levy, R., Kong H., Orr, G., \& King J. (Eds.). (2018). The Cambridge handbook of deliberative constitutionalism. Cambridge: Cambridge University Press.

Liebenberg, S. (2018). Participatory justice in social rights adjudication. Human Rights Law Review, 18(4), 623-649.

Malaysian Economic Association. (2017). MEA proposal: Enhancing parliamentary committees in Malaysia. Kuala Lumpur: Malaysian Economic Association, Faculty of Economics \& Administration, University of Malaya.

Manin, B. (1987). On legitimacy and political deliberation. Political Theory, 15(3), 338368.

Marinac, A. (2003). The Usual Suspects? Civil Society and Senate Committees. Papers on Parliament No 42. Canberra: Parliament of Australia, Canberra. Retrieved from $<$ https://www.aph.gov.au/sitecore/content/Home/About_Parliament/Senate/Powers practice_n_procedures/pops/pop42/ /link.aspx?_id=1AF5557C98A84D45A0ACC B0E6C36945D $>$. Accessed 10 Jan 2020.

Mashaw, J. L. (1981). Administrative due process: The quest for a dignitary theory. Boston University Law Review, 61, 885-931. 
Mauzy, D. K. (2006). The challenge to democracy: Singapore's and Malaysia's resilient hybrid regimes. Taiwan Journal of Democracy, 2(2), 47-68.

Means, G. P. (1996). Soft authoritarianism in Malaysia and Singapore. Journal of Democracy, 7(4), 103-117.

Mohd Hishamudin Yunus, Parliamentary select committees. In Legal Herald (December 2016), Lee Hishammuddin Allen \& Gledhill. Online <https:/www.lh-ag.com/wpcontent/uploads/2017/01/7828_Legal-Heral-Dec_v3.pdf $>$

Moulds, S. (2016). Committees of influence: Parliamentary committees with the capacity to change Australia's counter-terrorism laws. Australasian Parliamentary Review, 31(2), 46-66.

Moulds, S. P. (2018). The rights protecting role of parliamentary committees: The case of Australia's counter-terrorism laws (Doctoral thesis). University of Adelaide, Adelaide, South Australia, Australia.

Moulds, S. (2019). The role of Commonwealth parliamentary committees in facilitating parliamentary deliberation: A case study of marriage equality reform. In J. Debeljak \& L. Grenfell (Eds.), Law making and human rights, Chapter 24, Sydney: Thomson Reuters).

Mulgan, R. (1996). The Australian senate as a 'House of Review'. Australian Journal of Political Science, 31(2), 191-204.

Nagel, T. (1987). Moral conflict and political legitimacy. Philosophy and Public Affairs, 16(3), 215-240.

Orr, G., \& Levy, R. (2016). Regulating opinion polling: A deliberative democratic perspective. University of New South Wales Law Journal, 39(1), 318-340.

Pakatan Harapan. (2018). Buku harapan: Rebuilding our nation, fulfilling our hopes. Online $<$ http://kempen.s3.amazonaws.com/manifesto/Manifesto_text/Manifesto_PH_ EN.pdf $>$

Parliament of Australia, House of Representatives Standing Committee on Procedure, Parliament of Australia, Building a modern committee system: An inquiry into the effectiveness of the House committee system (2010). Retrieved from $<\mathrm{https}: / /$ www.aph.gov.au/Parliamentary_Business/Committees/House_of_Representatives_ Committees?url=proc/committees $2 /$ report.htm $>$.

Pettit, P. (2001). Deliberative democracy and the case for depoliticising government. University of New South Wales Law Journal, 24(3), 724-736.

Rankin, M. J. (2010). The absurdity of representation. Alternative Law Journal, 35(3), 130131.

Russell, M., \& Meghan B. (2009). Assessing the policy impact of parliament: Methodological challenges and possible future approaches. Paper presented at the Public Service Association Legislative Studies Specialist Group Conference. London, United Kingdom, 24 June 2009.

Ryan, M. (2019, April 12). Can Belgium's deliberative democracy experiment work in Australia? The Mandarin. Online <https://www.themandarin.com.au/107169-canbelgiums-deliberative-democracy-experiment-work-in-australia/>

Sedition Act to be abolished, says Liew. (2019, May 10) The Star. Online $<$ https://www. thestar.com.my/news/nation/2019/05/10/sedition-act-to-be-abolished-says-liew> 
Smookler, J. (2006). Making a difference? The effectiveness of pre-legislative scrutiny. Parliamentary Affairs, 59(3), 522-535.

Stubbs, M. (2012). A brief history of the judicial review of legislation under the Australian constitution. Federal Law Review, 40(2), 227-252.

Tolley, M. C. (2009). Parliamentary scrutiny of rights in the United Kingdom: Assessing the work of the Joint Committee on Human Rights. Australian Journal of Political Science, 44(1), 41-55.

Turner, P. N. (2014). "Harm” and Mill's Harm Principle. Ethics, 124(2), 299-326.

Vijaindren, A. (2018, August 8). Select committee, a positive progress in parliamentary reform, says C4. The New Straits Times. Online https://www.nst.com.my/news/ nation/2018/08/399440/select-committee-positive-progress-parliamentary-reformsays-c4

Westminster Foundation for Democracy, (2018) London Declaration on Post-Legislative Scrutiny (online) <https://www.wfd.org/approach/post-legislative-scrutiny/>. Accessed 10 Jan 2020.

Williams, G., \& Burton, L. (2015). Australia's parliamentary scrutiny act: An exclusive parliamentary model of rights protection. In M. Hunt, H. J. Hooper \& P. Yowell (Eds.), Parliaments and human rights: Redressing the democratic deficit (257-277). Oxford: Hart Publishing.

Williams, G., \& Reynolds, D. (2016). The operation and impact of Australia's parliamentary scrutiny regime for human rights. Monash University Law Review, 41(2), 469-507.

Zakaria, H. A. (1989). Malaysia: Quasi-democracy in a divided society. In L. Diamond, J. Linz \& S. M. Lipset (Eds.), Democracy in developing countries: Asia (Vol.3) (pp. 347-381). Boulder, CO: Lynne Rienner Publishers. 